\title{
Google Classroom: The Web-Based Media for Teaching English
}

\author{
Widi Andewi ${ }^{1 *}$, Dwi Pujiastuti ${ }^{2}$ \\ Information Systems, STMIK Pringsewu Lampung \\ Pringsewu, Lampung, Indonesia \\ *Corresponding Author. e-mail: widiandewi.mpd@gmail.com
}

\begin{abstract}
This study investigates whether: 1) Google Classroom is more effective than conventional method for teaching writing; 2) The high creativity students have better writing skills than those who have low creativity, and; 3) Interaction between teaching method and students' creativity in teaching writing occurs. This quasi-experimental study was conducted at STMIK Pringsewu in the academic year of 2020/2021. The sample of this research was two classes, the namely experimental class taught using Google Classroom, and the control class taught using a conventional method. Each class consisted of 20 students, so the total sample is 40 students. The sample was obtained by using the cluster random sampling technique. Each class was divided into two groups, consisting of ten high creativity students and ten low creativity students. The data of this research were obtained from a writing test to find out students' writing scores. Then, the data were analyzed by using $2 \times 2$ multifactor analysis of variance ANOVA and Tukey test. The results show that the mean scores of $A_{1} B_{1}$ are $82.40, A_{2} B_{1}$ is $75.30, A_{1} B_{2}$ is 68.70 , and $A_{2} B_{2}$ is 69.70. This study implies that Google Classroom is an effective method in teaching writing and is suitable to be implemented to those having high creativity.
\end{abstract}

Keywords: google classroom, writing, student's creativity

\section{Google Classroom: Media Berbasis Web untuk Mengajar Bahasa Inggris}

\begin{abstract}
Abstrak
Penelitian ini menyelidiki apakah: 1) Google Classroom lebih efektif daripada metode konvensional dalam mengajar menulis; 2) Siswa yang kreativitasnya tinggi memiliki kemampuan menulis yang lebih baik dibandingkan siswa yang kreativitasnya rendah; dan 3) Terjadi interaksi antara metode pengajaran dan kreativitas siswa dalam pembelajaran menulis. Penelitian kuasi eksperimen ini dilakukan di STMIK Pringsewu pada tahun pelajaran 2020/2021. Sampel penelitian ini memiliki dua kelas yaitu kelas eksperimen yang diajar menggunakan Google Classroom dan kelas kontrol yang diajar dengan metode konvensional. Setiap kelas terdiri dari 20 siswa, sehingga jumlah sampel adalah 40 siswa. Sampel diperoleh dengan menggunakan teknik cluster random sampling. Setiap kelas dibagi menjadi dua kelompok yang masing-masing terdiri dari 10 siswa kreativitas tinggi dan 10 siswa kreativitas rendah. Data penelitian ini diperoleh dari tes menulis untuk mengetahui nilai menulis siswa. Kemudian data dianalisis dengan menggunakan analisis multifaktor varians $2 \times 2$ dan uji Tukey. Hasil penelitian menunjukkan bahwa nilai rata-rata $A_{1} B_{1}$ adalah 82,40, $A_{2} B_{1}$ adalah 75,30, $A_{1} B_{2}$ adalah 68,70, dan $A_{2} B_{2}$ adalah 69,70. Hasil penelitian ini mengimplikasikan bahwa Google Classroom merupakan metode yang efektif dalam pengajaran menulis dan cocok untuk diterapkan bagi mereka yang memiliki kreativitas tinggi.
\end{abstract}

Kata kunci: google classroom, menulis, kreativitas siswa

How to Cite: Andewi, W. \& Pujiastuti, D. (2021). Google classroom: The web based media for teaching english. Jurnal Penelitian Ilmu Pendidikan, 14(2), 189-198. doi: https://doi.org/10.21831/jpipfip.v14i1.41450.

Received 16-06-2021; Received in revised from 21-07-2021; Accepted 21-08-2021

This is an open-access article under the $\underline{\mathrm{CC}-\mathrm{BY}-\mathrm{SA}}$ license. 


\section{Jurnal Penelitian Ilmu Pendidikan, 14 (2), 2021 - 190 \\ Andewi \& Pujiastuti}

\section{INTRODUCTION}

In this modern era, learning activity is no longer enclosed within face-to-face interaction - the process of teaching changes rapidly because of the COVID-19 pandemic. Hastomo (2019) states that the current teacher is anticipated to accelerate superior learning activity inside and outside the classroom, known as beyond the classroom activity. This learning environment utilizes individualized, proficiency-based, and student center movement. To facilitate such a situation, the foremost obstacle is escalating reliance on technology, which is central to modern students (Halverson et al., 2017). In this era, the students are surrounded by technology where they are employing smartphones and notebooks for entertainment purposes and accessing educational media, such as Google Classroom. Since the use of gadgets is improving significantly, it is prominent to the technology dependence among students. This statement is supported by Keumala, Yoestara, \& Putri (2018) who state that giving access to gadgets and the internet for students can contribute to negative impacts such as mental disorders, learning problems, attention deficit, and speech delay that can cause the students' behavior.

Some students are consuming time with their gadgets. They are affectionate with the use of digital technology that they cannot control in their daily activities. The teachers and parents are very concerned about this gadget era. Since this technology is growing, Google launched a web-based learning media whose name is Google Classroom. This media transformed as a constructive instance of technology since it ensures an individualized, flexible learning environment that utilizes learning beyond the classroom. Google Classroom offers various features that can help simplify the procedure of grading assignments and tests in a paperless activity that makes this an advantage of online learning.

Furthermore, teachers and students have a connection to deliberate subject matter outside the classroom without meeting face-to-face, so this free application supports distance learning. Google Classroom is the only application designed specifically for the education sector. It is a unique phenomenon because it is free of charge and free of ads, supporting student learning activities. Iftakhar (2016) defines Google Classroom to assist educators in managing and collecting paperless student assignments such as Google Docs, Drive, and other applications. Teachers can focus on developing students' potential because Google Classroom allows teachers to spend more time with their students.

Google Classroom is a free cloud-based service widely used by all academics because it has authentic and professional technology that is useful for learning purposes (Keeler, 2014). For example, a teacher can publish announcements, send emails, give assignments, or hold exams. In addition, user data is not used for advertising purposes, so there are no ads in the Google Classroom interface. Students can $\log$ in to Google Classroom, and they can find a timeline that appears with many posts related to learning activities such as discussion forums, assignments, quizzes, and exams. This feature can be used as a place for student discussion in expressing opinions by creating discussion topics. Teachers can introduce students to e-portfolio strategies by using Google Drive in archive storage media and assignments. Both students and teachers can share document files. In addition, the students can collaborate online using shared folders if they work on projects in groups. This event is how group works can be conducted effectively to improve cooperation between classmates.

It is not a new movement for utilizing technologies for teaching English. The use of computer-assisted initiated in 1960. In this era, students are widespread with the help of smartphones for their daily use. Since Google Classroom is an application that can be accessed using a smartphone, several papers try to investigate the prospect of Google Classroom and barriers in terms of using it as educational media for teaching English. Google Classroom is one of the best online platforms for learning activities because it offers many innovative, new features and supports student assessment (Al-Maroof \& Al-Emran, 2018). The e-learning process can be well promoted by using Google Classroom so that the education community highly accepts its presence. It integrates traditional classrooms with web-based technology. The literature data that discusses this innovative technology occurs because of the wide acceptance by teachers and students. A web-based learning program can 


\section{Jurnal Penelitian Ilmu Pendidikan, 14 (2), 2021 - 191 \\ Andewi \& Pujiastuti}

be utilized as an online learning medium for carrying out no face-to-face classes by instructors (Hastomo, 2019).

There are new challenges in providing education through different ways, such as the assistance received by students and teachers through Google Classroom (Northey, Bucic, Chylinski , \& Govind, 2015). First, anyone can access this application using Google Application for Teaching Instruction, such as Docs, Drive, and Gmail. Practicality's popularity stands out in Google Classroom and flexibility for organizing the work and saving time. Second, students can easily access this app through a smartphone, PC, or laptop. In the first six months of estimated usage, there were thirty million student assignments accepted by Google Classroom. Third, E-learning-based learning media is closely related to Google Classroom so that there are recommendations for this application by various educational communities (Northey et al., 2015). Finally, Google Classroom can reach many students without going through face-to-face activities, eliminating travel costs and flexibility in study schedules.

Several researchers have appreciated learning English using technology, such as Northey et al., (2015), Hastomo (2019), and Heggart \& Yoo (2018), but some educators consider this method is not as effective as traditional learning methods such as Manca \& Ranieri (2016), Henrie, Halverson, \& Graham (2015), and Pienta (2016). For example, Northey et al., (2015) explain that blended learning can create a student-focused learning environment supported by activities inside and outside the classroom. Moreover, Everson, Gundlach, \& Miller (2013) and Heggart \& Yoo, (2018) define online material to engage students in the mixed learning field. Nevertheless, Pienta, (2016) affirmed his concerns regarding the problems students can find to complete their work outside the classroom. Similarly, Halverson et al., (2017) discovered several obstacles in carrying out online learning: student privacy and differences in learning objectives between student and institutions. Furthermore, the finding conflict between student goals and institutional goals were also demonstrated by Dabbagh \& Kitsantas (2012) and Manca \& Ranieri (2016).

Student creativity is another factor that influences students' writing skills besides learning media technology. Hastomo (2016) explains that creativity is students' thinking ability in expressing new ideas, concepts, and projects that have a crucial role in dealing with learning problems. Creativity must be related to the characteristics possessed by students such as aspects of learning, actions, activities, thoughts, and ideas. Meanwhile, Sternberg (2006) reveals that creativity is an effort made to obtain an actual idea and realize the idea into a real product. Students can express new ideas, commit to assignments, and be open to experiences during the teaching and learning process. Thus, students with high creativity can produce a text with quite complex ideas, new topics, and correct grammar compared to students with low creativity.

In summary, the researchers examined the use of Google Classroom in learning English. So far, many studies have discussed the acceptance of Google Classroom as a learning medium and academics' perceptions of this application. However, no research discusses Google Classroom research in terms of student creativity. So, the researchers investigate the effectiveness of Google Classroom on students' writing ability in English as a Foreign Language (EFL) viewed students' creativity in Indonesia.

\section{METHODS}

Experimental research is the research method used in this study. The college students from STMIK Pringsewu were taken as the population in this research. The researchers had taught in STMIK Pringsewu for four years so that the researchers already know about the students' characteristics in the teaching-learning process. The researchers are the lecturers from this university so that it can be accessible for the researcher to research STMIK Pringsewu. And this research employed a quasi-experimental design as a research design. Simple factorial design $2 \mathrm{x} 2$ with PostTest Only Design is a research design in this research. To determine the control and experimental group, the research subjects were chosen. Both groups were given post-tests at the end of treatments. In this research design, both groups were assigned to different treatments based on experimental and control conditions. A post-test examined the students in both classes in the form of a written test. The 


\section{Jurnal Penelitian Ilmu Pendidikan, 14 (2), 2021 - 192 \\ Andewi \& Pujiastuti}

researchers analyzed the data by employing post-test scores through Multifactor Variance (ANOVA) $2 \times 2$ and Tukey test.

The second-semester students of Informatic System students were the population of this study in the academic year of 2020/2021. Cluster random sampling is used by researchers to determine the research sample. Cluster random sampling is a sampling technique where the researchers determined the sample based on a group of natural individuals simultaneously (Ary, Jacobs, \& Sorensen, 2010). The existence of an average score and the same number is the reason the researchers employed class selection. Next, the lottery was used to determine the two classes that were used by the researchers. The researchers asked one of the representatives from the two classes to take a paper with the name "Google Classroom" or "Conventional Method" to determine the class that acts as the experimental class and the control class. There are 40 students as a population of this research, and each course consisted of 20 students.

In this study, a writing test and a creativity test were measured using two research instruments. The researchers obtained the results of students' creativity level by holding a creativity test which was applied before the treatment was carried out. Meanwhile, students' writing tests were held to determine students' writing skills which included five characteristics, namely mechanics, grammar, vocabulary, organization, and content. Furthermore, the inter-rater is used by researchers to minimize subjectivity when assessing the writing score. The writer will calculate the average score of the two assessors as the final writing score. Meanwhile, the use of questions to determine the readability of the written instructions and creativity tests and writing tests was held to understand and read the two test instructions. In addition, there is an objective to identify sufficient time allocation or not. Based on the readability test between the two tests, there were findings that students could read and understand the test instructions without any problems.

For analyzing the data, descriptive analysis and inferential analysis were employed by the researchers. Descriptive research was chosen to find the mean, mode, median, and standard deviation of the written test result. Before conducting the hypothesis, the researchers utilized the normality and homogeneity tests. The multifactor analysis of variance $2 \times 2$ is the inferential analysis used in this study. $\mathrm{H}_{\mathrm{o}}$ is rejected if $\mathrm{F}_{\mathrm{o}}$ is higher than $\mathrm{F}_{\mathrm{t}}$. Tukey test was conducted if Ho was rejected to investigate which class was better.

\section{Result}

\section{RESULT AND DISCUSSION}

In this research, the writer conducted a normality test and homogeneity test before examining the hypothesis of this paper using ANOVA 2x2 and Tukey Test. The researcher divided the data of the research into eight groups: (1) $A_{1}$ is the student's writing data applying Google Classroom; (2) $A_{2}$ is the student's writing data applying the Conventional Method; (3) $\mathrm{B}_{1}$ is a writing test data for high creativity students; (4) $B_{2}$ is the writing test data of low creativity students; (5) $A_{1} B_{1}$ is the writing data of high creativity students who use Google Classroom; (6) $A_{1} B_{2}$ is the writing test data of low creativity students who use Google Classroom; (7) $\mathrm{A}_{2} \mathrm{~B}_{1}$ is the writing test data of high creativity students using the Conventional Method; (8) $\mathrm{A}_{2} \mathrm{~B}_{2}$ is the writing data of low creativity students who use the Conventional Method.

There are eight groups as the result of normality test, namely: (1) the highest value of $L_{o}$ is 0.152 with $\mathrm{L}_{t}$ is 0.190 as $\left(\mathrm{A}_{1}\right)$ the writing score calculation results of the students applying Google Classroom, (2) the highest value of $\mathrm{L}_{\mathrm{o}}$ is 0.178 with $\mathrm{L}_{\mathrm{t}}$ is 0.190 as $\left(\mathrm{A}_{2}\right)$ the writing scores calculation result of the students applying Conventional Method, (3) the highest value of $\mathrm{L}_{\mathrm{o}}$ is 0.134 with $\mathrm{L}_{\mathrm{t}}$ is 0.190 as $\left(B_{1}\right)$ the writing scores calculation result of the high creativity students, (4) the highest value of Lo is $0.142 \mathrm{Lt}$ is 0.190 as (B2) the writing scores calculation result of the low creativity students, (5) the highest value of $\mathrm{L}_{\mathrm{o}}$ is 0.148 with $\mathrm{L}_{t}$ is 0.258 as $\left(\mathrm{A}_{1} \mathrm{~B}_{1}\right)$ the writing scores calculation result of the high creativity students applying Google Classroom, (6) the highest value of $\mathrm{L}_{\mathrm{o}}$ is 0.192 with $\mathrm{L}_{\mathrm{t}}$ is 0.258 as $\left(\mathrm{A}_{1} \mathrm{~B}_{2}\right)$ the writing scores calculation result of low creativity the students applying Google Classroom, (7) the highest value of $\mathrm{L}_{o}$ is 0.237 with $\mathrm{L}_{t}$ is 0.258 as $\left(\mathrm{A}_{2} \mathrm{~B}_{1}\right)$ the writing scores calculation result of the high creativity students taught applying. Conventional Method, and (8) the 
highest value of $\mathrm{L}_{\mathrm{o}}$ is 0.142 with $\mathrm{L}_{\mathrm{t}}$ is 0.258 as $\left(\mathrm{A}_{2} \mathrm{~B}_{2}\right)$ the writing scores calculation result of the low creativity students applying Conventional Method. The researchers obtained $\mathrm{L}_{\mathrm{t}}\left(\mathrm{L}_{\text {table }}\right)$ at the level of significance $\alpha=0.05$ is higher than $\mathrm{L}_{\mathrm{o}}$ ( $\mathrm{L}_{\mathrm{obtained}}$ ), so the data is normal. Then, $\mathrm{L}_{\mathrm{t}}$ at the level of significance $\alpha=0.05$ is higher than $\mathrm{L}_{\mathrm{o}}$ of the entire data $\left(\mathrm{L}_{\mathrm{t}}>\mathrm{L}_{\mathrm{o}}\right)$, so the writing scores of eight groups data have a normal distribution. Table 1, ilustrated about the summary of normality test.

Table 1. The Summary of Normality Test

\begin{tabular}{|c|c|c|c|c|c|c|}
\hline No & Variables & $\begin{array}{l}\text { Number } \\
\text { of data }\end{array}$ & $\mathrm{L}_{\mathrm{o}}$ & $\mathrm{L}_{\mathrm{t}}$ & Description & $\begin{array}{c}\text { Test } \\
\text { Discussion }\end{array}$ \\
\hline 1 & $\begin{array}{l}\text { Writing Scores of the Students Taught by } \\
\text { Google Classroom }\left(A_{1}\right)\end{array}$ & 20 & 0.152 & 0.190 & Normal & $\mathrm{H}_{\mathrm{o}}$ is accepted \\
\hline 2 & $\begin{array}{l}\text { Writing Scores of the Students Taught by } \\
\text { Conventional Method }\left(\mathrm{A}_{2}\right)\end{array}$ & 20 & 0.178 & 0.190 & Normal & $\mathrm{H}_{\mathrm{o}}$ is accepted \\
\hline 3 & $\begin{array}{l}\text { Writing Scores of the Students Having High } \\
\text { Creativity }\left(B_{1}\right)\end{array}$ & 20 & 0.134 & 0.190 & Normal & $\mathrm{H}_{\mathrm{o}}$ is accepted \\
\hline 4 & $\begin{array}{l}\text { Writing Scores of the Students Having Low } \\
\text { Creativity }\left(B_{2}\right)\end{array}$ & 20 & 0.142 & 0.190 & Normal & $\mathrm{H}_{\mathrm{o}}$ is accepted \\
\hline 5 & $\begin{array}{l}\text { Writing Scores of the Students Having High } \\
\text { Creativity Taught by Google Classroom } \\
\left(A_{1} B_{1}\right)\end{array}$ & 10 & 0.148 & 0.258 & Normal & $\mathrm{H}_{\mathrm{o}}$ is accepted \\
\hline 6 & $\begin{array}{l}\text { Writing Scores of the Students Having Low } \\
\text { Creativity Taught by Google Classroom } \\
\left(A_{1} B_{2}\right) \\
\text { Writing Scores of the Students Having High }\end{array}$ & 10 & 0.192 & 0.258 & Normal & $\mathrm{H}_{\mathrm{o}}$ is accepted \\
\hline 7 & $\begin{array}{l}\text { Creativity Taught by Conventional Method } \\
\left(\mathrm{A}_{2} \mathrm{~B}_{1}\right)\end{array}$ & 10 & 0.237 & 0.258 & Normal & $\mathrm{H}_{\mathrm{o}}$ is accepted \\
\hline 8 & $\begin{array}{l}\text { Writing Scores of the Students Having High } \\
\text { Creativity Taught by Conventional Method } \\
\left(\mathrm{A}_{2} \mathrm{~B}_{2}\right)\end{array}$ & 10 & 0.142 & 0.258 & Normal & $\mathrm{H}_{\mathrm{o}}$ is accepted \\
\hline
\end{tabular}

There is a number 1.59 as a result of the homogeneity test in this study. The data can be said to be homogeneous because $\chi_{t}^{2}(7.81)$ is higher than $\chi_{0}^{2}(1.59)$ at the significance level $=0.05$. Thus, $\chi_{\text {table }}\left(\chi_{t}^{2}\right)$ is higher than $\chi_{\text {obtained }}\left(\chi_{0}^{2}\right)$ in this study. Therefore, the researchers conclude that the sample used is homogeneous.

Table 2. The Mean Scores

\begin{tabular}{cccc}
\hline & $\mathrm{A}_{1}$ & $\mathrm{~A}_{2}$ \\
\hline $\mathrm{B}_{1}$ & 82.40 & 75.30 & 78.85 \\
$\mathrm{~B}_{2}$ & 68.70 & 69.70 & 69.20 \\
\hline Total & 75.55 & 72.50 & 74.03 \\
\hline
\end{tabular}

Based on Table 2, Google Classroom has higher effectiveness than Conventional Methods for teaching writing because the average $A_{2}$ (72.50) is lower than $A_{1}$ (75.55). It is obtained from the significant difference between the columns, and $\mathrm{H}_{\mathrm{o}}$ is rejected, based on the significance level $=0.05$ (4.0), i.e. $\mathrm{F}_{\mathrm{t}}$ is lower than $\mathrm{F}_{\mathrm{o}}$ between columns (5.50).

Moreover, the high creativity students have better writing skills than low creativity students. This statement is obtained from the average $B_{2}$ (69.20) lower than the average $B_{1}$ (78.85). There is a significant difference between low creativity students and high creativity students. This statement is obtained from significant differences between rows, and $\mathrm{H}_{\mathrm{o}}$ is rejected, and $\mathrm{F}_{\mathrm{t}}$ at a significance level of $=0.05$ (4.08) is lower than $\mathrm{F}_{\mathrm{o}}$ between rows (55.07).

Furthermore, the level of student creativity affects the effectiveness of the learning methods used. Moreover, in teaching writing, there is an interaction between students' creativity and teaching methods. This statement is obtained from the rejection of $\mathrm{H}_{0}$. The researchers found that $\mathrm{F}_{\mathrm{t}}$ at significance level $=0.05(4.08)$ is lower than $F_{o}$ column by rows $(9.70)$. 


\section{Jurnal Penelitian Ilmu Pendidikan, 14 (2), 2021 - 194 Andewi \& Pujiastuti}

Table 3. The Summary of ANOVA $2 \times 2$

\begin{tabular}{lccccr}
\hline \multicolumn{1}{c}{ Source of Variance } & SS & Df & MS & $\mathbf{F}_{\mathbf{o}}$ & $\mathbf{F}_{\mathbf{t}(\mathbf{0 0 5})}$ \\
\hline Between columns (The Teaching & 93.025 & 1 & 93.025 & 5.50 & 4.08 \\
Methods) & & & & & \\
Between rows (Creativity) & 931.225 & 1 & 931.225 & 55.07 & \\
Columns by rows (Interaction) & 164.02 & 1 & 164.02 & 9.70 & \\
Between groups & 1188.27 & 3 & 396.09 & & \\
Within groups & 608.70 & 36 & 16.91 & & \\
\hline Total & 1796.98 & 39 & & & \\
\hline
\end{tabular}

Based on Table 3, the researchers apply Multifactor Variance (ANOVA) 2x2 as a data analysis method if the data has been declared homogeneous and normal. The impact of the dependent variable on the attributive variable and the independent variable was identified through the application of the test. The interaction between these variables was also examined using this test. A hypothesis is rejected if $\mathrm{F}_{\mathrm{o}}$ is higher than $\mathrm{F}_{\mathrm{t}}\left(\mathrm{F}_{\mathrm{o}}>\mathrm{F}_{\mathrm{t}}\right)$.

The Tukey test was used by the researchers to compare the mean of each treatment against the average of other treatments. Thus, researchers can determine whether the dependent variable has an interaction and is influenced by the independent variable. Table 4 presents a summary of the data.

Table 4. The Summary of Tukey Test

\begin{tabular}{lcccl}
\hline \multicolumn{1}{c}{ Data } & Sample & qo & qt & \multicolumn{1}{c}{ Status } \\
\hline A1 - A2 & 20 & 3.32 & 2.95 & Significant \\
B1 - B2 & 20 & 10.50 & 2.95 & Significant \\
A1B1- A2B1 & 10 & 5.46 & 3.15 & Significant \\
A1B2- A2B2 & 10 & 0.77 & 3.15 & Not Significant \\
& & & & \\
\hline
\end{tabular}

The researchers will explain the data in Table 4. For teaching writing, Google Classroom is more effective than the Conventional Method. It happens because the average $\mathrm{A}_{2}$ (72.50) is lower than $A_{1}$ (75.55) so that in learning to write, the implementation of Google Classroom is significantly different from the Conventional Method. It is supported by (2.95) $\mathrm{q}_{\mathrm{t}}$ at the level significance $\alpha=0.05$, which is lower than (3.32) $\mathrm{q}_{\mathrm{o}}$ between columns $\left(\mathrm{A}_{1}-\mathrm{A}_{2}\right)$.

Moreover, the high creativity students have better writing skills than low creativity students. It happens because the average $\mathrm{B}_{2}(69.20)$ is lower than $\mathrm{B}_{1}$ (78.85). Moreover, there are significant differences in teaching writing for high creativity students and low creativity students based on than $\mathrm{q}_{\mathrm{t}}$ at the level significance $\alpha=0.05$ (3.15), which is lower than $\mathrm{q}_{\mathrm{o}}$ between columns $\left(\mathrm{B}_{1}-\mathrm{B}_{2}\right)(10.50)$.

Google Classroom is more effective than the Conventional Method for teaching writing for high creativity students. It happens because the average $\mathrm{A}_{2} \mathrm{~B}_{1}$ (75.30) is lower than $\mathrm{A}_{1} \mathrm{~B}_{1}$ (82.40). Moreover, there is a significant difference in the application of Google Classroom with the Conventional Method for high creativity students based on $\mathrm{q}_{\mathrm{t}}$ at the level significance $\alpha=0.05$ (2.95) lower than inter-cell $\mathrm{q}_{\mathrm{o}}$ between cells $\left(\mathrm{A}_{1} \mathrm{~B}_{1}-\mathrm{A}_{2} \mathrm{~B}_{1}\right)(5.46)$.

Google Classroom is as effective as the Conventional Method for teaching writing to low creativity students. This statement is obtained from the difference between the columns is not significant for students with low creativity because $\mathrm{q}_{\mathrm{t}}$ at the level significance $\alpha=0.05$ (2.95) is higher than the inter-cell $\mathrm{q}_{\mathrm{o}}$ between cells $\left(\mathrm{A}_{1} \mathrm{~B}_{2}-\mathrm{A}_{2} \mathrm{~B}_{2}\right)(0.77)$.

\section{Discussion}

\section{The Difference between Google Classroom and Conventional Method}

For teaching writing, there is a significant difference between the use of Google Classroom and the Conventional Method based on the findings of this study. The average score of students who use Google Classroom is higher than students who use the Conventional Method. Thus, the authors 
conclude that Google Classroom has higher effectiveness than the conventional method for teaching writing.

Based on the observation of the researcher, students can contribute actively and act positively by using Google Classroom as teaching media. There are several benefits provided by Google Classroom, such as students can increase their confidence to write text in English because they get feedback from classmates and teachers, gain easy access to learning materials that have been provided in Google Classroom, and take part in lessons from various the place. It is supported by Albashtawi \& Al Bataineh (2020) that Google Classroom can motivate students to improve their English skills enthusiastically compared to direct instruction.

Meanwhile, learning activities centered and dominated by teachers are reflected in conventional methods. Students do not have the opportunity to make decisions in class. The process and steps of student learning are determined by teacher guidance in this teaching method. The teacher only provides information and explains the material directly by demonstrating the structure of the text in stages. Furthermore, students will get a text and analyze the text structure and arrange the text based on the text that has been studied. So that the main focus in transferring information in conventional methods is the teacher. Students can be passive, and they are not enthusiastic because of these problems. Learning to write in English requires students to be more active, but conventional methods encourage students to be passive and dependent on the teacher (Hastomo, 2016).

\section{The Difference between High Creativity Students and Low Creativity Students}

The researcher concludes that high creativity students produce better writing skills than low creativity students. This statement is obtained from students' mean scores for students with low creativity that are lower than students with high creativity.

The high creativity students have increased enthusiasm for completing assignments well, carrying out teacher instructions, and learning well. Students' creativity will be needed to write good English texts. This statement is accompanied by the existence of media and learning methods to achieve learning targets. Wang (2019) explains that creative individuals are focused, disciplined, and diligent. So that students with high creativity can produce writing with more complex concepts. Based on this statement, students' writing ability is influenced by their level of creativity. This statement is supported by Khodabakhshzadeh, Hosseinnia, Moghadam, \& Ahmadi (2018) which states that a high level of student creativity will produce a varied and complex composition of writing.

Nevertheless, passive students are often associated with low levels of creativity. These students have monotonous creations, ideas, and concepts while writing text in English. They are unable to convey new opinions or beliefs in class and only provide outdated examples. They are unable to explore ideas because they do not dare not to limit their creative thinking. These students only write based on what they hear, read, and see because their creativity level is low. This statement is supported by Marashi (2017) who explains that students with low creativity tend to spend a relatively long time planning, have difficulty solving problems, and have new ideas. In addition, students with low creativity will produce writing similar to those of other students not to create anything new. Hu \& Wei, (2019) added that students who are not creative would work on assignments in a hurry to look for shortcuts to produce writing with ideas that are not original.

Interaction between Teaching Methods and Students' Creativity on the Students' Writing Skills

The study results explained that students 'writing skills were influenced by the learning methods and students' creativity. The data explains that Google Classroom has a significant effect on conventional methods for learning to write for have high creative students. Still, the difference is not substantial for low creativity students.

Google Classroom has various features that can help facilitate various tasks, activities, and discussions systematically so that Google Classroom will be more effective in supporting the writing skills of high creativity students. This statement is supported by Azhar \& Iqbal (2018), that Google Classroom creates a sustainable, interactive learning environment consisting of active participation, student collaboration, student communication, and student interaction with teachers.

The high creativity students dare to express ideas, dare to take risks, increased selfconfidence, flexible thinking, heightened curiosity, great interest, initiative, and high imagination 
power. Fonseca \& Soto Peralta, (2019) stated that creative students have a series of mental abilities, a mental activity with multiple goals that lead to communication with other people, problem-solving, recognizing or generating ideas, offering choices, and desires that are strong.

Students with low creativity have different characteristics from creative students. Such students tend to act recklessly, follow other ideas, are not initiated, and are passive. They write English texts to fulfill their responsibilities without improving their writing skills, so they do not want to think further. Creative thinking is a demand that must be avoided because they prefer something simple and like to be guided. This statement is in line with Mota Pereira (2016) who explains that students who are not creative are reluctant to create something new, are afraid of failure, and do not attach importance to creativity.

The low creativity students are not enthusiastic about participating in any activity. They are unable to express new ideas and pass them on to other students. Furthermore, they are also not ready for a challenging task or activity. So, the result of the text that is done is a job with an idea that is too ordinary, it even tends to copy and paste the answers on the internet. McLellan \& Nicholl (2013) stated that if there are several characteristics for students who are not creative, namely lack of creative thinking skills, lack of diversity of knowledge, lack of curiosity, lack of confidence, less rebellion, less fun, less challenge, lack of achievement drive, lack of passion, and a lack of inspiring vision.

Students' writing skills can be supported by conventional methods and Google Classroom for low creativity students based on the characteristics above. It happens because the student cannot demonstrate the ability to produce an English text well. After all, it has more minor creative features. Yagcioglu (2016) explains that certain strategies or learning media do not significantly influence students who have a low level of creativity. Thus, the authors conclude that the conventional method has the same effectiveness as Google Classroom for students who have low creativity.

\section{CONCLUSION}

Based on the results of the explanation above, the researchers conclude several research findings, namely (1) Google Classroom has high effectiveness in teaching writing compared to conventional methods, (2) In the writing subject, there are differences in learning outcomes by high creativity students and low creativity students, (3) In the writing subject, there is an interaction between learning methods and students' creativity. In this case, the students who apply Google Classroom show that the high creativity students have better writing results than low creativity students in writing subjects. Meanwhile, when they were taught through the Conventional Method, there were results that students with low creativity had better writing results compared to students with high creativity.

Thus, the researchers already prepared research suggestions that: 1) In writing learning activities, lecturers should use Google Classroom because this learning platform offers many benefits; 2) Students should be accustomed to using Google Classroom because they can obtain a better learning process, create efficiency and flexibility in teaching and learning activities, and become more independent learners; 3) The researchers who will examine the effectiveness of Google Classroom with learning English can use different population characteristics or variables such as gender, economy, and so on.

\section{REFERENCES}

Albashtawi, A. H., \& Al Bataineh, K. B. (2020). The effectiveness of google classroom among efl students in Jordan: An innovative teaching and learning online platform. International Journal of Emerging Technologies in Learning, 15(11), 78-88. https://doi.org/10.3991/IJET.V15I11.12865.

Al-Maroof, R. A. S., \& Al-Emran, M. (2018). Students acceptance of google classroom: An exploratory study using pls-sem approach. International Journal of Emerging Technologies in Learning, 13(6), 112-123. https://doi.org/10.3991/ijet.v13i06.8275. 
Ary, D. Jacobs, \& Sorensen. (2010). Introduction to research in education: 8th (eight) Edition (8th ed.). Cengage Learning. https://www.amazon.com/Donald-Ary-Introduction-ResearchEducation/dp/B008UBNO0E.

Azhar, K. A., \& Iqbal, N. (2018). Effectiveness of google classroom: Teachers' perceptions. Prizren Social Science Journal, 2(2), 52-66.

Dabbagh, N., \& Kitsantas, A. (2012). Personal learning environments, social media, and selfregulated learning: A natural formula for connecting formal and informal learning. Internet and Higher Education, 15(1), 3-8. https://doi.org/10.1016/J.IHEDUC.2011.06.002.

Everson, M., Gundlach, E., \& Miller, J. (2013). Social media and the introductory statistics course. Computers in Human Behavior, 29(5), A69-A81. https://doi.org/10.1016/J.CHB.2012.12.033.

Fonseca, K. A. B., \& Peralta, F. S. (2019). Google classroom: An effective virtual platform to teach writing in an efl composition course. International Journal of English Language Teaching, 6(1), 27. https://doi.org/10.5430/ijelt.v6n1p27.

Halverson, L. R., Spring, K. J., Huyett, S., Henrie, C. R., \& Graham, C. R. (2017). Blended learning research in higher education and k-12 settings. Learning, Design, and Technology, 1-30. https://doi.org/10.1007/978-3-319-17727-4_31-1.

Hastomo, T. (2019). Schoology effects on students' writing ability. Lentera: Jurnal Ilmiah Kependidikan, 12(1), 149-154.

Hastomo, T. (2016). The effectiveness of edmodo to teach writing viewed from students motivation. Proceeding of International Conference on Teacher Training and Education 1(1), 580-585.

Heggart, K. R., \& Yoo, J. (2018). Getting the most from google classroom: A pedagogical framework for tertiary educators. Australian Journal of Teacher Education, 43(3), 140-153. https://doi.org/10.14221/ajte.2018v43n3.9.

Henrie, C. R., Halverson, L. R., \& Graham, C. R. (2015). Measuring student engagement in technology-mediated learning: A review. Computers \& Education, 90, 36-53. https://doi.org/10.1016/J.COMPEDU.2015.09.005.

Hu, J., \& Wei, Y. (2019). The centrality of creativity: A new perspective on English language teaching. English Today, 35(2), 60-61. https://doi.org/10.1017/S0266078418000299.

Iftakhar, S. (2016). Google classroom: What works and how? Journal of Education and Social Sciences, 3. http://www.ucalgary.ca/ dmjacobs/phd/diss/Image74.gif.

Keeler, A. (2014). 20 things you can do with google classroom-teacher tech. https://alicekeeler.com/2014/09/07/20-things-google-classroom/.

Keumala, M., Yoestara, M., \& Putri, Z. (2018). The impacts of gadget and Internet on the Implementation of Character Education on Early Childhood. Proceedings of the ICECED, 313-325.

Khodabakhshzadeh, H., Hosseinnia, M., Moghadam, H. A., \& Ahmadi, F. (2018). Efl teachers' creativity and their teaching's effectiveness: A structural equation modeling approach. International Journal of Instruction, 11(1), 227-238. https://doi.org/10.12973/iji.2018.11116a.

Manca, S., \& Ranieri, M. (2016). Facebook and the others: Potentials and obstacles of social media for teaching in higher education. Computers \& Education, 95, 216-230. https://doi.org/10.1016/J.COMPEDU.2016.01.012.

Marashi, H. (2017). Using cooperative learning to boost creativity and motivation in language learning. Journal of Language and Translation, 7(1), 43-58. https://www.researchgate.net/publication/324310825_Using_Cooperative_Learning_to_Boost _Creativity_and_Motivation_in_Language_Learning.

McLellan, R., \& Nicholl, B. (2013). Creativity in crisis in design \& technology: Are classroom climates conducive for creativity in English secondary schools? Thinking Skills and Creativity, 9, 165-185. https://doi.org/10.1016/J.TSC.2012.11.004.

Northey, G., Bucic, T., Chylinski, M., \& Govind, R. (2015). Increasing student engagement using asynchronous learning. Journal of Marketing Education, 37(3), 171-180. https://doi.org/10.1177/0273475315589814. 


\section{Jurnal Penelitian Ilmu Pendidikan, 14 (2), 2021 - 198 \\ Andewi \& Pujiastuti}

Pereira, F. M. (2016). Creativity in the English language classroom. In ELT Journal (Vol. 70, Issue 3). https://doi.org/10.1093/elt/ccw040.

Pienta, N. J. (2016). A "flipped classroom" reality check. Journal of Chemical Education, 93(1), 1-2. https://doi.org/10.1021/acs.jchemed.5b00996.

Sternberg, R. J. (2006). The nature of creativity robert. Creativity Research Journal, 18(1), 87-98. https://doi.org/10.1207/s15326934crj1801.

Wang, H. C. (2019). Fostering learner creativity in the English L2 classroom: Application of the creative problem-solving model. Thinking Skills and Creativity, 31, 58-69. https://doi.org/10.1016/J.TSC.2018.11.005.

Yagcioglu, O. (2016). Increasing creativity with the self-studies in basic English classes. European Journal of English Language Teaching, 1(2), 59-77. https://doi.org/10.5281/zenodo.166305. 